\title{
The Effects of Social Security Privatization on Household Saving: Evidence from the Chilean Experience
}

\author{
Julia Lynn Coronado \\ Federal Reserve Board of Governors
}

February, 1997

\begin{abstract}
In recent years, a handful of countries have converted the financing of their social security systems from pay-as-you-go (PAYGO) to partial or full funding. Privatization is viewed as one way to insulate social security from the political and demographic pressures that currently threaten the financial stability of PAYGO systems. However, privatization would improve a nation's situation only if such a reform increases domestic saving. In this paper 1 use evidence from Chile, where social security was privatized in 1981, to assess the impact of such a reform on household saving rates. I find that the reform provided a significant stimulus for saving among higher income households, increasing their saving rates by more than seven percentage points. This increase in saving at the household level translates into an increase in national saving of more than two percent of GDP.
\end{abstract}

I would like to thank Dan Slesnick, Dean Maki, Jan Walliser, Peter Brady, John Sabelhaus, Al Teplin, Len Burman, Don Fullerton, and participants at the Tax Economists Forum for helpful comments. Research funding from the National Science Foundation is gratefully acknowledged. The views expressed in this paper are those of the author and do not necessarily reflect the views of the Federal Reserve Board or its staff. 


\section{Introduction}

In recent years, a handful of countries have converted the financing of their social security systems from pay-as-you-go (PAYGO) to partial or full funding. These reforms generally have also transferred some of the management of contributions to the private sector. Many more countries are considering similar reforms as declining birth rates and longer life expectancy have left their PAYGO social security systems underfunded. Bringing these systems back into balance would require large tax increases or benefit cuts. Privatization is viewed as one way to insulate social security from the political and demographic pressures that currently threaten the financial stability of PAYGO systems.

Underfunding of a social security system implies that future claims on resources exceed what is effectively being set aside. The only solution is to increase resources dedicated to funding the consumption of current and future retirees.

Privatization would improve a nation's situation only if such a reform increases domestic saving (Greenspan 1997). National saving will be affected by the change in the method of financing and how transition to a fully-funded system is structured. Financing and transition impacts of privatization have been widely analyzed. However, transition from a PAYGO to a fully-funded system will also affect household saving, not only in an accounting sense as social security saving is transferred from government to households, but because households may also adjust their net of social security saving in response to perceived changes in the value and risk of future social security wealth. The impact of privatization on household saving has received less attention.

In this paper I use evidence from Chile, where social security was privatized in 1980 , to assess the impact of such a reform on household saving rates net of social security. In Chile, transfer from the PAYGO system to the private system was voluntary. I employ data from a household income expenditure survey and implement a difference in difference approach to compare the saving behavior of those covered under the private system and those who remained in the PAYGO system. I find that 
privatization of social security had a negligible effect on net of social security saving rates among medium and low income households. However the reform provided a significant stimulus for saving among higher income households.

Section II of this paper provides a brief overview of the Chilean reform. Section III provides a discussion of what impact privatization might be expected to have from a theoretical perspective. Recent literature which has looked at the effects of privatization and existing evidence on the effect of the Chilean reform is also reviewed. Section IV describes the data. Section V presents the empirical approach and discusses the strengths and weaknesses of the difference in difference methodology which has been used widely in recent years to measure responses to changes in policy. The results are presented in section VI and section VII concludes with a discussion of their implications.

\section{Social Security Privatization in Chile}

Prior to the reform of 1980 , Chile had a social security system financed exclusively on a PAYGO basis. The system was administered by a handful of institutions organized by occupational categories. Employees and employers contributed a percentage of wages with the employer contribution generally much larger than the employee contribution. The system did not achieve universal coverage. Self-employed and informal sector workers, who make up 25 to 30 percent of the labor force, were not covered by the system. In addition to providing old age pensions, the social security institutions provided disability and survivor's pensions, worker compensation and unemployment insurance, and health care benefits.

Discussions of reform began in the early 1960 s due to problems of long-run solvency. The population growth rate was declining and life expectancy was increasing at the same time the system was maturing, implying a rapidly growing passive to active ratio. Responding to political pressures, benefits had also been increased and extended prior to this time. These factors combined to place unsustainable financial strain on the system. The response was to increase the payroll 
tax. By the late 1960s the employer and employee contribution was close to 50 percent of wages (Iglesias and Acuna 1991). Critics cited the distortionary impact of the payroll tax, the high administrative costs of the multiple institutions, and the instability of real benefits due to frequent congressional interference in indexation rules in calling for privatization.

The social security system introduced in 1980 is based on full capitalization of contributions. Participants have ten percent of their wages deducted and placed in a personal account in a financial institution of their choosing. There is no employer contribution, however employers pay for worker compensation insurance. An additional percentage, generally between three and four percent of wages, is deducted to cover administrative costs and disability and survivor's insurance. In addition to the mandatory contribution, people can make additional contributions to their accounts tax free up to a generous cap. Financial institutions called Pension Fund Administrators were established to exclusively handle the management of pension funds. Their investment mix is regulated by the government. Upon retirement as individual chooses between the purchase of an indexed annuity and a sequence of withdrawals.

Transition to the new system was voluntary. Participants who switched to the private system were issued indexed recognition bonds for the amount of contributions they had made under the PAYGO system. Approximately 70 percent of participants in the PAYGO system switched to the new system in the first year of operation. Those who remained were older workers closer to retirement (Mesa-Lago 1994).

\section{Social Security and Household Saving Behavior}

The life cycle model has long been the most predominant context for thinking about saving behavior. The basic theoretical model predicts that people will attempt to keep their marginal utility of expenditure constant over their lives. The implication is that people will save to insure their consumption streams against a number of contingencies, the principle one being old age. Despite the predictions of the life 
cycle model, there has been longstanding concern that people do not save "enough." If people do not save enough to insure themselves then the government will likely have to fill the void which presents a catch-22 situation. Evidence suggests that the existence of government insurance programs lead people to save less (Hubbard, Skinner, and Zeldes 1995). Low saving means less funds for capital accumulation, economic growth and Improvements in economic well-being. The decline in U.S. saving over the past few decades has been accompanied by a decline in domestic investment, productivity growth, and growth in real wages (Gokhale, Kotlikoff and Sabelhaus 1996). The concern over low saving has been followed up with a variety of policies aimed at encouraging people to set aside more resources.

By far the largest scale policy intervention in household saving decisions is social security. Social security forces people to save over the life cycle and thereby provide for their own retirement needs. As long as providing for old age is one reason people save, contributions to social security should serve as a partial substitute for personal saving and therefore reduce net of social security saving rates at the household level. The degree to which contributions to social security affect saving rates depends on the future benefits participants expect to draw. Expectations of future benefits are influenced by expected rate of return on contributions, clarity of information regarding benefit structures, expected future stability of the system, the value placed on certain types of insurance provided by the system, and a host of other factors.

A number of papers have documented the extent to which the presence of social security depresses household saving rates, including Feldstein and Pelecchio (1979), Kotlikoff (1979), Diamond and Hausman (1984), Dicks-Mireaux and King (1984), Bernheim (1987), and Leimer and Richardson (1992). As most social security systems are financed on a PAYGO basis, any reduction in household saving translates into a decline in aggregate saving as contributions to social security are simply transferred from the working generation to retirees. So while a social security system may ensure that people insure themselves over the life cycle, it reduces the funds available for capital accumulation. 
Demographic and political factors have contributed to long run solvency problems in many PAYGO social security systems. Among reform options for addressing these problems, privatization of social security has received increasing attention. Privatization generally refers to making the transition from a PAYGO system to a fully-funded one where some of the management of contributions is handled by the private sector. Such a social security system would continue to force people to save for retirement while channeling a large and stable source of funds into the private sector for investment. The short and long run impact of privatization on national saving depends on how the transition is structured and financed and the behavioral responses of individuals and households. In this paper my focus is on the effect of privatization on saving at the household level. Specifically, I examine the impact of the reform on net of social security household saving rates.

\section{Privatization and Household Saving}

The effect of social security privatization on household saving decisions will depend on the ways the reform impacts current income and expected future wealth. In a life cycle context, some potential effects of privatization would lead to increases in household saving, some would decrease saving, and other effects are theoretically ambiguous.

Transition to a system in which contributions are invested in private markets implies a significantly different set of risks faced by households. At the very least households would be expected to react to social security reform by restructuring their portfolios. If households believe they face increased risks under a private system, they may also increase their levels of saving outside the social security system.

While transition from the PAYGO to the private system was voluntary under the Chilean reform, a significant reduction in the payroll tax provided a powerful incentive to make the transfer. As part of the reform, the employer contribution was phased out and partially passed on to employees for those that remained in the PAYGO system. Gruber (1995) found that employees bore the burden of the employer contribution under the PAYGO system. To ensure that the reduction in 
employer contribution rates was passed on to employees, the government mandated a one time increase of 18 percent in the gross wages of all workers. However, for those that remained in the PAYGO system, the average contribution rate (across the different social security institutions) was almost 26 percent of wages. Those who transferred to the new system paid a maximum of 17 percent of wages which included a contribution of four percent for health insurance. The average increase in disposable income for those who made the switch to the new system was 11.6 percent on average (Arellano 1985). Assuming no change in the rate of return, a decrease in contribution rates would mean a decrease in wealth upon retirement. If the initial rate of contribution was what the household wanted to save for retirement, they will save some of the increase in disposable income which could lead to increased saving rates. If it was more than they wanted to save for retirement, they may consume most of the increase in income.

The reform may have also changed the extent to which households view the payroll tax as a pure tax versus a form of saving. Privatization is widely believed to increase the perceived marginal benefit per dollar of contribution to social security (Kotlikoff 1996, Feldstein 1996). In another paper I found evidence that the Chilean reform marginally increased this tax-benefit linkage inherent in the payroll tax (Coronado 1997). Holding other factors constant, an increase in the perceived value per dollar of contributions translates into an increase in effective wages as contributions to social security are viewed as a better substitute for saving. This increase in the lifetime wage profile would facilitate higher levels of consumption at every age and households may save more to facilitate increased consumption in retirement.

The reform also included a tax incentive for saving in that people can make additional contributions to their accounts tax free up to a limit which is currently close to $\$ 1600$ a month. However in Chile, only people at the upper end of the income distribution are subject to income taxation. Approximately 40 percent of the labor force pays income tax. For these households, the reform may have provided an important stimulus for saving due to the tax incentives. I will analyze the change in 
saving behavior resulting from privatization separately for tax and non tax payers because of the differing potential impacts of the reform.

The way the transition is financed potentially alters the relative price of current and future consumption and could therefore impact household saving choices. The transition deficit in Chile has been largely financed through the implementation of a value added tax. Such a consumption tax increases the price of current consumption and may induce households to save more.

One of the most frequently cited benefits to privatization is the increased return to contributions. Under A PAYGO system, the return to contributions will be limited to growth in productivity and the labor force, whereas contributions under a fully funded system earn a generally higher market rate of return. In Chile contributions to the private system have certainly earned a higher rate of return than what would have been realized had the PAYGO system been left in place. Since social security saving in inframarginal, an increased rate of return would only have an income effect. Holding contribution rates constant, an increase in the expected rate of return implies an increase in retirement wealth which could decrease net of social security household saving rates.

Privatization may also induce labor supply responses which could alter lifetime wealth and therefore saving. The payroll tax under a PAYGO system is thought to be fairly distortionary for a number of reasons (Feldstein 1996). If privatization reduces the distortionary impact of the tax, and in fact lowers the tax rate as in Chile, this may increase or decrease labor supply depending on whether the income or substitution effect dominates. Labor supply responses could also come in the reform of changing the timing of retirement which induce changes in saving decisions. Because the overall theoretical prediction is ambiguous, the effect of privatization on household saving is a question which must be addressed empirically.

\section{Previous Literature on the Effects of Privatization}

Many papers that have analyzed the effects of privatization have not addressed the issue of household saving responses to such a reform. A number of recent papers 
have outlined reforms and estimated their implications for national saving and economic welfare. These papers include Feldstein and Samwick (1997), Kotlikoff (1996), Altig and Gokhale (1997), Huang, Imorohoroglu, and Sargent (1995), and Mariger (1997). None of these studies makes assumptions about directions and magnitudes of responses to privatization in household net of social security saving rates. While not making an assumption is understandable due to the theoretical ambiguity, significant reactions in household saving behavior could have important implications in estimating the overall impact on national saving and capital formation attributable to such a reform. The nature of any saving response would also provide an indication of the changes in value and risk perceived by households.

Empirical work which has looked at the impact of the Chilean reform has focused on aggregate measures of saving. National saving increased dramatically following privatization. Many have claimed that social security reform is directly responsible for this increase, while others claim that it is largely due to increased economic growth experienced over the same period. Different authors have deconstructed national saving in a variety of ways to try and get at the effect of the reform. Holzmann (1997) estimates the impact on saving due to the reform as net contributions to the new system minus the deficit for the old system and the recognition bonds issued to those who switched systems. He finds the initial impact was negative but that the effect of the reform has been more than two percent of GDP annually throughout the 1990s. Holzmann's measure captures the effect on national saving of the change in financing of social security, but neglects any responses in household saving induced by the reform. Hachette (1997) calculates the mandatory component of total private saving as contributions to the new system but then points out that it is impossible to distinguish between business and household saving in the remaining voluntary component of private saving. Table 1 shows various measures of national saving. While voluntary private saving has increased dramatically since the reform, aggregate figures reveal little about behavioral responses. 


\section{Data on Household Saving}

Data on saving behavior come from a household income expenditure survey conducted by the National Institute of Statistics. The data were collected over a period of twelve months, from December 1987 through November 1988. Households were selected randomly and interviewed in their homes over a period of three months. Data was collected on household and personal expenses, ownership of durables, characteristics of the house, self-reported imputed rent for homeowners, income from a variety of sources for each household member, and the demographic characteristics of the household. Data is provided for 5076 households residing in the greater Santiago metropolitan area.

\section{Defining Household Saving}

I define saving as total household income net of taxes minus total expenditure. This is a broad based saving measure which will allow me to capture overall saving responses and abstract from the shifting of the composition of household portfolios. I add income from all sources across all members of the household. Labor income is combined with capital and transfer income and imputed rent from owner-occupied housing. For wage and salary workers, the data on labor income is net of all deductions for taxes and social security contributions. For self-employed workers labor income is business income net of costs. The saving rate I estimate is therefore net of taxes and social security contributions.

I account for the investment in, and consumption of durables by estimating a service flow from durable ownership. Using average price data for used durables taken from a Santiago daily newspaper, I estimate a resale value for a variety of durables and then compute a service flow from their ownership using a constant rate of depreciation. ${ }^{1}$ This service is flow is then added to total household income and expenditure. I subtract current expenditure on durables from reported expenditure. I

1. My methodology is a simplified version of an approach developed by Van der Gaag et al. (1983). 
also subtract any mortgage payments for home owners and include imputed rent in total expenditure as an estimate of housing consumption. Accounting for housing and durables in this way means saving is also net of durables investment.

Saving at the household level is a notoriously noisy measure as both income and consumption are measured with error which is then compounded in calculating saving (see discussion in Browning and Lusardi 1996). Figure 1 plots saving rates by household income. Several features of the data are interesting to note. First, there is a highly skewed income distribution. It is also clear that there is a positive relationship between saving rates and income. In calculating a rate, I am already controlling for income. The figure therefore indicates a nonlinear relationship between income and saving. While the positive relationship is evident, there is also a wide dispersion of saving rates at lower levels of household income. Some differences in saving at similar income levels is expected as households may be at very different points in the life cycle.

Figure 2 plots average household saving rates by age of household head. The life cycle pattern is clear in this picture. The variation in bar height is due to a small number of observations for some ages and the general noisiness of the saving measure. Table 2 provides key summary statistics. The difference between the median and the mean saving rate reflect the influence of the large negative observations depicted in Figure 1. The remaining four measures reflect the wide dispersion in household saving rates. I will address the noisiness of the saving measure in several ways in the econometric analysis. As I add a new component of noise in estimating a service flow for durables, I will also perform my analysis with a savings measure calculated as income minus expenditure with no accounting for housing or other durables as a means of checking the robustness of my results.

\section{Defining Coverage Status}

In my analysis of saving I take advantage of the fact that the data include people covered under the PAYGO system and people covered under the private system. As stated earlier, transition to the private system was voluntary. Those who 
remained in the PAYGO system were older workers. Combining information from the government agency that regulates the private system with labor survey data from the University of Chile, I estimate that approximately 90 percent of workers covered by social security in 1988 who were under 40 were covered by the private system. Estimates of affiliation are less precise among older workers. I find that over half of all workers between the ages of 45 and 65 in 1988 who are covered by social security are covered by the PAYGO system. I therefore define households with a head under forty as affiliated with the private system and those with a head 45 to 65 as affiliated with the PAYGO system. The presence of older workers who are actually affiliated with the private system will bias toward zero any estimated impact of privatization.

I cannot directly compare the saving decisions of households covered under the private and PAYGO systems as they are at very different stages of the life cycle. Instead I employ a difference in difference approach in which the self-employed serve as my control group. I discuss this approach in more detail in the next section. While the self-employed were not covered under the PAYGO system, they are free to affiliate with the private system. It was hoped the reform would draw more selfemployed into social security coverage. In fact this has not occurred. In 1988, the self-employed accounted for less than three percent of private system participants while they accounted for more than 25 percent of the labor force (Iglesias and Acuna 1991). It is therefore reasonable to designate households where the head is selfemployed and the spouse does not work in covered employment as not being covered under any social security system. I compare the saving behavior of those covered by the private and PAYGO systems relative to their self-employed counterparts.

Finally, I subdivide the sample into tax and non-tax payers. For those who do not pay taxes, any estimated change in saving behavior can be attributed to the effects of social security privatization. For those who do pay taxes, any estimated impact of the reform will be due to both privatization and the tax incentive for saving. As the income tax is levied on an individual basis, I define a household where either spouse is subject to the income tax as a tax paying household.

Summary statistics for the saving rates of non-tax paying households by social 
security coverage status are shown in Table 3. Effects of the reform will be reflected in relative differences between the private and PAYGO systems among covered and non-covered groups. Non-tax paying households with heads less than 40 are both relatively low income and at the early stages of the life cycle so that, on average, both the covered and non-covered are dissavers. The median saving rate for both groups is slightly positive, however, and in both statistics the covered save more (dissave less) than the non-covered. The saving behavior of the covered and non-covered is much more similar under the PAYGO system. While the mean has the covered saving about one percent more than the non-covered, the median reflects them saving one percent less. Table 5 gives information on the demographic characteristics of the different categories of non-tax paying households. What is remarkable is how similar the covered and non-covered are under each system. The only difference of note is that the covered under the private system earn more than the non-covered, which may help explain their relatively higher saving rates.

Information on the saving rates of tax paying households is given in Table 4. Again the covered save more than the non-covered under the private system as reflected by both the mean and median saving rates. Under the PAYGO system, the non-covered actually save more. Table 6 contains demographic information on tax paying households. Covered heads of household under the private system are more often college educated and non-covered under the PAYGO system are more often married, but again the main difference appears to be in income. The non-covered under the PAYGO system have significantly higher incomes than the covered which may explain their higher saving rates. Under the private system, the covered actually make slightly less and yet save more.

\section{Estimating Saving Responses: A Difference in Difference Approach}

I estimate a saving function and employ a difference in difference technique to identify the effect of privatization. As stated earlier, comparing the saving behavior of participants in the private and PAYGO systems directly would be inappropriate as they 
are at very different stages of their life cycles. Instead I ask the question: does the saving behavior of households affiliated with the new system differ from that of households affiliated with the old system relative to their self-employed counterparts?

Using the permanent income hypothesis as a guide, we know that saving should be a function of permanent income and age. Demographic characteristics are also relevant in determining household saving behavior. I specify that saving rates will depend on the demographic characteristics of the household, household income and a series of dummy variables which relate to the social security coverage status of the household. The saving function is as follows:

$$
S_{i}=\alpha+X_{i} \beta+\delta \text { new }_{i}+\gamma \text { covered }_{i}+\theta \text { new }_{i} * \text { covered }_{i}
$$

where $\mathrm{i}$ indexes households and $\mathrm{X}$ is a vector of household characteristics including income. The variable new is equal to one if the household head is less than forty and zero otherwise and the variable covered takes the value of one if the person is a wage or salary worker and zero otherwise. The interaction term new*covered is the difference in difference term. It captures differences in saving of those covered by the private system from those covered under the PAYGO system, relative to their selfemployed counterparts. As my dependent variable is the household saving rate, the estimated coefficient on new*covered will indicate the percentage point increase or decrease in saving rates attributable to the privatization of social security.

In recent years, the difference in difference approach has been used widely to estimate behavioral responses to tax policy. Examples of this work include Feenberg and Poterba (1993), Gruber and Poterba (1994), Gruber (1994), Feldstein (1995), and Maki (1997). In most cases the sample population is divided into those affected by the policy and those who are not. Data is used before and after the implementation of the policy under consideration. The first difference is over time, i.e. it reflects changes in the behavior of each group. The second difference is the difference in the first differences, i.e. it reflects how the behavior of those affected by the policy changes 
relative to those who were not affected. The approach is a powerful way of assessing the effects of policy changes provided the underlying assumptions hold. Identification of these models requires that the two groups do not differ systematically in a way that is correlated with the policy change (Goolsbee 1997).

The difference in difference technique is less common in a cross-sectional setting like the one I employ. Identification in this model requires the assumption that differences in saving rates between covered and non-covered households would be the same for young and old households if social security reform had never been implemented. This assumes that the timing of saving decisions across the life cycle is the same between wage and salary workers and the self-employed. This may not be the case if the timing of earnings is very different between the two groups. To test this assumption I use thirty-five years of cross sectional employment surveys, spanning the period from 1960 to 1994 , to estimate life-cycle earnings profiles for wage and salary workers and the self-employed. The dependent variable was the log of earnings of household heads, and the regressors included a dummy for gender, years of education, cohort dummies, year dummies, age and age squared. Using the coefficients from age and age squared, the relationship between earnings and age is plotted for wage and salary workers and the self-employed in Figure 3. While earnings of wage and salary workers peak a little earlier, both groups have similar convex timing of earnings across the life cycle. Similar earnings profiles do not necessarily translate into similar timing of saving, however the degree to which saving behavior can differ systematically between the two groups is limited.

\section{Analysis and Results}

\section{Preliminaries}

In dividing people into covered and non-covered groups, I have implicitly assumed that they are random sub-samples of the population. It is possible that people choose their coverage status based on a host of factors which are correlated with their personal attributes, implying a selection problem that would bias the results. Given 
that people have to participate a minimum number of years under either system to qualify for benefits, it is likely that people choose their coverage status early in life and do not change frequently making selection a negligible issue empirically. An examination of the demographic characteristics of covered and non-covered subsamples also does not reveal any systematic differences.

I have also sub-divided the sample into tax and non-tax payers. Taxpayer status is determined by income, which is in turn related to saving in a nonlinear fashion. In a difference in difference approach, the practical issue is whether the relative difference in the relationship between saving and income among covered and non-covered, new and old system participants is different by tax paying status. There is no theoretical reason to think this would be the case. I estimated the saving function pooling tax and non tax payers and found no evidence of significant bias. The results from that estimation are not presented here.

I included household income in my specification of the saving function. Current household income measures permanent income, however it is measured with error due to the transitory component of income. This random component implies bias in the coefficient estimates. This presents a catch 22 situation. Saving is a function of income, so if I do not include income as an explanatory variable I will have biased estimates. Yet income is measured with error, so if I do include income as a regressor I will have biased estimates. Ideally the measurement error could be addressed by instrumenting for income, however the data contain no appropriate instruments. Instead, I estimate the saving function with and without household income as a means of insuring that the results are robust to this bias.

The demographic variables in my specification of the saving function include the number of adults, the number of children, the age of the head, and dummy variables for whether the head is married, whether the head is male, and whether the head has a college education. The other variables are the three social security dummy variables and income. Table 7 shows the correlation coefficients among the explanatory and dependent variables for non tax payers. Table 8 shows the same information for tax payers. The signs and magnitudes of the correlation coefficients 
appear to be sensible and there do not appear to be correlations among regressors high enough to raise concerns of multicollinearity.

Some interesting patterns emerge with regard to education. While the dummy variable for whether the head has a college education has a strong, positive correlation with income, it is only weakly correlated with saving rates among both tax and nontax payers. This is in contrast to empirical evidence in the United States of a strong relationship between education and saving. The lack of a strong correlation between college education and saving could be because the education variable is poorly measured, or it may be that a strong relationship between education and saving may simply not exist in Chile. The relationship between eduaction and saving will show up as an anomaly in the econometric estimation.

\section{Estimation and Results}

It is not clear that the most useful way to understand the impact of social security privatization on household saving rates, is through the estimation of the reform's effect on mean saving rates. As was seen in section IV, both the distribution of income and saving rates are highly skewed and fraught with noise. The mean is overly influenced by extreme observations and the implications from a standard OLS regression may therefore be difficult to interpret. I control for the instability of the saving variable by using two alternative forms of estimation. The first is robust regression which is an iterative, weighted least squares procedure that controls for outliers. The second is median regression where absolute rather than squared deviations are minimized, and where the object is to predict the median of the dependent variable conditional on the values of the independent variables.

The results obtained from estimating a saving function for non tax payers using these two estimation techniques are presented in Table 9. Results are presented with and without household income as a regressor, and where the dependent variable was the saving rate which accounts for investment in and consumption of durables, and where the saving rate is defined simply taking current income minus current expenditure. T-statistics are shown in parentheses. Most of the estimated coefficients 
are consistent across specifications. Age has a positive and generally significant impact on saving rates. Children negatively impact household saving. The inclusion of household income significantly alters the estimated relationship of only two variables. The number of adults has a positive and significant impact on saving rates until income is added when the effect becomes negative and insignificant. The dummy for college education is positive and marginally significant until income is added when it becomes negative and strongly significant. A strong negative relationship between college education and saving is certainly counterintuitive, unless earnings risk is systematically higher for people of lower educational attainment. Higher earnings risk among less educated households may lead to a higher propensity for precautionary saving among these households, and this effect may show up only when income effects are accounted for.

None of the social security dummy variables are significant in any of the specifications for non tax payers. Social security coverage status does not appear to have a significant effect on the saving decisions made by the middle and lower income households. While the effect of the reform as measured by new*covered is positive, implying an increase in saving rates due to privatization, this effect is consistently insignificant.

The results of the estimation of saving functions for tax payers is shown in Table 10. Again, most coefficients are consistent across specifications. Children have a significant and negative effect on saving. The number of adults and age are not significant determinants of saving among tax payers. The negative relationship between college and saving that was observed for non tax payers is observed for tax payers once income is included.

Among tax payers, social security coverage status appears to have an important influence on net of social security saving decisions. The social security dummy variables new and covered are negative and strongly significant until income is included. They remain negative but are only marginally significant once household income is added to the regression. A negative coefficient on the variable new is expected as households covered by the new system are younger and therefore probably 
save less. A negtative coefficient on the variable covered probably reflects the fact that, while the saving variable captures net of social security saving among covered households, it measures total personal saving for the non-covered and so should be lower in general for the covered. The variable new*covered, which captures the effects of the reform is strongly positive and significant across all specifications. The estimated increase in saving rates attributable to privatization ranges from 7.8 percentage points to 18 percentage points.

\section{Interpretation and Conclusions}

The evidence presented here suggests that higher income households save significantly more outside of social security due to privatization. As discussed in section III, there are a number of reasons why this might be the case. One of the most obvious interpretations is that the increased saving among higher income households is a response to the tax incentive included in the Chilean reform. Discussions with Augusto Iglesias, former director of research for one of the pension fund administrators, cast doubt on this interpretation. Responses to the tax incentive can be measured by the contributions people make to their social security accounts above the mandatory contribution. Very few participants in the private system made additional contributions to their accounts in 1988, the year the data used in this analysis were collected. Additional contributions have become increasingly common in recent years among higher income participants in the private system as they get older and closer to retirement, however that is apparently not the response that is being captured here. The savings response I find appears to be solely due to the impacts of the privatization of social security.

As social security accounts are the only vehicle for tax-deferred saving, the lack of additional contributions to these accounts may be an indication that the increased saving is being channeled into more liquid forms of saving to satisfy precautionary motives. Precautionary saving against earnings risk is likely to be a relatively more important motivation for saving among younger households (Engen 
and Gale 1997). If the increase in disposable income realized by those who made the transition to the private system has been saved in more liquid instruments, perhaps the PAYGO system had forced younger households to oversave for retirement.

Households may perceive increased risk exposure under the private system and respond by increasing their net of social security saving. Even if retirement is the principal motivation for saving, households may seek to hedge their risk exposure by channelling their saving into safer assets than those held by pension fund administrators. The composition of risks inherent in the returns to social security contributions are very different under the PAYGO and private systems. Table 11 shows the average annual rates of return to Chilean pension funds since privatization. While only the upside risk has been realized until very recently, the overall risk faced by participants in the private system as measured by the variation in returns is likely much higher than what they faced under the PAYGO system. Increased risk exposure would help explain increased net of social security saving.

An increase in the perceived marginal benefit per peso of contribution to social security brought about by privatization would translate into a shifting upward of lifetime wage profiles for those who made the transition to the new system. The implied increase in lifetime income would help explain increased saving as individuals would want to save more during their working years to raise the level of their retirement consumption. In other work I found evidence that the reform increased the tax-benefit linkage (Coronado 1997), and this increase in effective lifetime wages may help explain the increase in saving rates.

Privatization may also have affected saving propensities. The defined contribution plan may have made the process of retirement saving more transparent and educated the participants in the new system on saving and investing in general. Thus, the Chilean reform may have increased households' "taste" for saving.

Sorting out the potential explanations for increased saving would require data that contain greater detail on asset allocation. The analysis here suggests only that households responded to the privatization of social security by increasing their overall net of social security saving rates. By looking at saving rates, and controlling for 
income, I have abstracted from the effects of the strong economic growth experienced after privatization. The difference in difference approach allowed me to identify behavioral shifts in saving rates attributable to privatization. While the evidence of increased saving among lower income households is fairly weak, I found strong and robust evidence of increased saving among higher income households.

The results presented here indicate that tax payers covered by the new system increased their saving rates by at least 7.8 percentage points. Using factors of expansion included in the data, I estimated that there were 724,912 tax paying households covered under the private system in 1988. Multiplying the number of households in this group by their mean and median income and an increase in saving of 7.8 percentage points, I calculated that the effect of the reform in 1988 was to increase aggregate private saving net of social security by 2.8 and 2.4 percent of GDP, respectively. This impact on national saving would likely increase as those who switched to the new system reach their peak saving years, and as new people enter the labor force and are covered by the private system.

In reforming an underfunded system, the only long-term solution is to increase the resources being set aside to fund the consumption of current and future retirees (Greenspan 1997). My research indicates that, in Chile, privatization was effective in that it led to an increase in household and national saving. An analysis of asset allocation among households would be useful in sorting out the underlying causes of the saving response. Understanding the reasons for the increased saving would also help determine how likely a similar response might be in other countries that privatize their social security systems. 


\section{References}

Altig, David and Jagadeesh Gokhale. "Social Security Privatization: A Simple Proposal." Working Paper No. 9703, Federal Reserve Bank of Cleveland, April 1997.

Arellano, Jose Pablo. Politicas Sociales y Desarollo. Santiago, Chile: CIEPLAN 1985.

Bernheim, Douglas. "The Economic Effects of Social Security: Toward a Reconciliation of Theory and Measurement." Journal of Public Economics, vol 33, 1987, pp. 273-304.

Bosworth, Barry P. and Manuel Marfan. "Saving, Investment, and Economic Growth." In Bosworth, Dornbusch, and Laban eds., The Chilean Economy: Policy Lessons and Challenges, Washington, D.C. : The Brookings Institution, 1994.

Browning, Martin and Annamaria Lusardi. "Household Saving: Micro Theories and Micro Facts." Journal of Economic Literature, vol 34(4), December 1996, pp. 1797-1855.

Coronado, Julia Lynn. "The Impact of Social Security Privatization on Perceived Marginal Benefit and Pre-Retirement Labor Supply: Evidence from the Chilean Reform." mimeo, Federal Reserve Board of Governors, 1997.

Diamond, Peter A. and Jerry A. Hausman. "Individual Retirement and Savings Behavior." Journal of Public Economics, vol 23, February/March 1984, pp. 81-114.

Dicks-Mireaux, Louis and Mervyn King. "Pension Wealth and Household Savings: Tests of Robustness." Journal of Public Economics, vol 23, February/March 1984, pp. 115-39.

Engen, Eric M. and William G. Gale. "The Effects of Social Security Reform on Private and National Saving." Forthcoming in Social Security Reform: Links to Saving, Investment and Growth, Federal Reserve Bank of Boston.

Feenberg, Daniel R. and James M. Poterba. "Income Inequality and the Incomes of Very High-Income Taxpayers: Evidence from Tax Returns." in James Poterba ed., Tax Policy and the Economy, Cambridge, Ma: MIT 1993, pp. 145-77. 
Feldstein, Martin. "The Missing Piece in Policy Analysis: Social Security Reform." The American Economic Review, vol 86(2), May 1996, pp. 1-14.

"The Effect of Marginal Tax Rates on Taxable Income: A Panel Study of the 1986 Tax Reform Act." Journal of Political Economy, vol 103(3), 1995, pp. 551-72.

and Anthony Pellechio. "Social Security and Household Wealth Accumulation: New Microeconomic Evidence." The Review of Economics and Statistics, 61(3), August 1979,pp. 361-68.

and Andrew Samwick. "The Economics of Prefunding Social Security and Medicare Benefits.” NBER Working Paper No. 6055, June 1997.

Gokhale, Jagadeesh, Laurence J. Kotlikoff, and John Sabelhaus. "Understanding the Postwar Decline in U.S. Saving: A Cohort Analysis." Brookings Papers on Economic Activity, 1, 1996, pp. 315-90.

Goolsbee, Austan. "It's Not About Money: Why Natural Eperiments Don't Work on the Rich." Mimeo, University of Chicago, October 1997.

Greenspan, Alan. Statement before the Task Force on Social Security, Committee on the Budget, U.S. Senate. November 1997.

Gruber, Jonathan. "The Incidence of Payroll Taxation: Evidence from Chile." NBER Working Paper No. 5053, March 1995.

. "The Incidence of Mandated Maternity Benefits." The American Economic Review, vol 84(3), June 1994, pp. 622-641.

and James Poterba. "Tax Incentives and the Decision to Purchase Health Insurance: Evidence from the Self-Employed." Quarterly Journal of Economics, August 1994, pp. 701-733.

Hachette, Dominique. "Private Saving in Chile." Unpublished manuscript, Catholic University of Chile, March 1997.

Holzmann, Robert. "Pension Reform, Financial Market Development, and Economic Growth: Preliminary Evidence from Chile.” IMF Staff Papers, vol 44(2), 1997

Hubbard, R. Glenn, Jonathan Skinner, and Stephen P. Zeldes. "Precautionary Saving and Social Insurance." Journal of Political Economy, vol 102(2), April 1995, pp.360-99. 
Huang, He, Selahattin Imrohoroglu, and Thomas Sargent. "Two Computational Experiments to Fund Social Security." Mimeo, USC, October 1995.

Iglesias, Augusto. "Efectos de la Reforma Sobre el Ahorro y el Mercado de Capitales." Santiago, Chile: PrimAmerica Consultants, 1997. and Rodrigo Acuna. Chile: Experiencia con un Regimen de Capitalizacion 1981-1991. Santiago, Chile: CEPAL, 1991.

Kotlikoff, Laurence J. "Testing the Theory of Social Security and Life-Cycle Accumulation." The American Economic Review, vol 93(2), June 1979, pp. 396-410.

- "Privatization of Social Security: How it Works and Why It Matters." in James Poterba ed., Tax Policy and the Economy, Cambridge, Ma: MIT 1996.

Leimer, Dean R. and Selig D. Lesnoy. "Social Security, Uncertainty Adjustments and the Consumption Decision." Economica, vol 59(235), August 1992, pp. 31135 .

Maki, Dean M. "Household Debt and the Tax Reform Act of 1986." Mimeo, Federal Reserve Board of Governors, March 1997.

Mariger, Randall P. "Social Security Privatization: What it Can and Cannot Accomplish." mimeo, Federal Reserve Board of Governors, June 1997.

Mesa-Lago, Carmelo. Changing Social Security in Latin America: Toward Alleviating the Social Costs of Economic Reform. Boulder, Colorado: Lynne Reinner Publishers, 1994.

Morande, Felipe. "Savings in Chile: What Went Right?" Inter-American Development Bank Working Paper No. 322, 1996.

Van der Gaag, Jacques, Sheldon Danziger, and Eugene Smolensky. "The Life-Cycle Hypothesis and the Consumption Behavior of the Elderly." Journal of Post Keynesian Economics, 5, 1983, pp. 208-27. 
Figure 1 - Household Saving Rates by Income

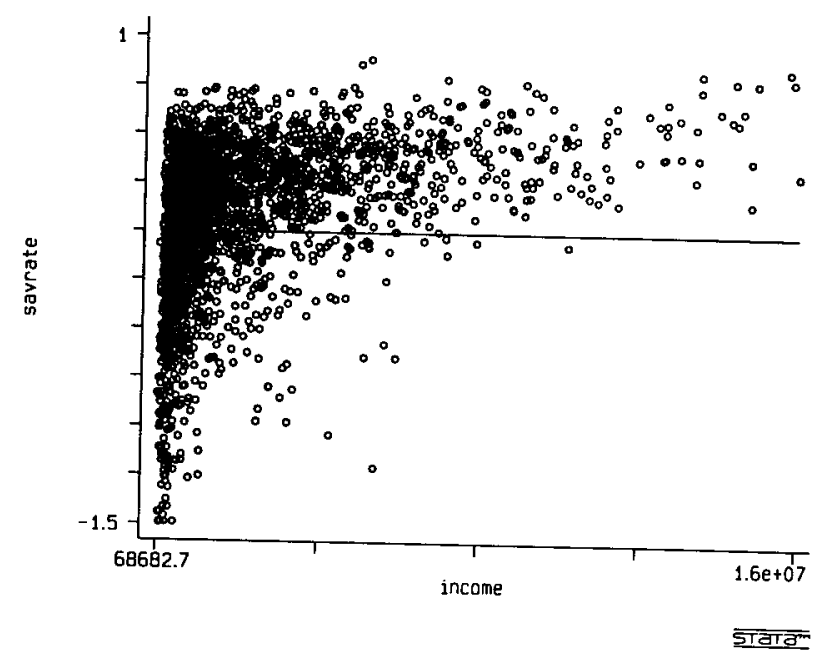

Figure 2 - Household Saving Rates by Age of Head

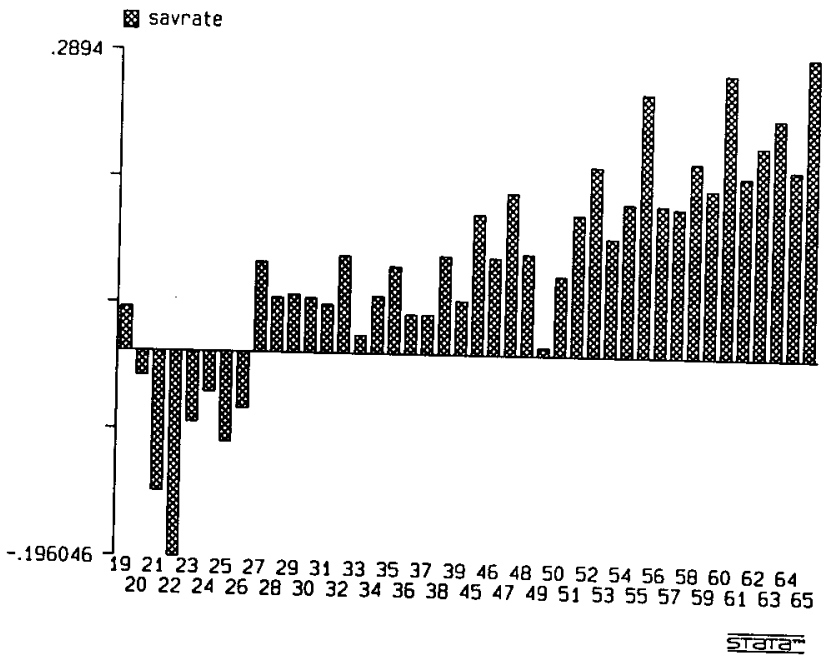


Table 1 - Selected Measures of National Saving in Chile as a Percentage of GDP

\begin{tabular}{|c|c|c|c|c|c|}
\hline Year & $\begin{array}{c}\text { National } \\
\text { Saving }\end{array}$ & $\begin{array}{c}\text { Social } \\
\text { Security } \\
\text { Saving - New } \\
\text { System* }\end{array}$ & $\begin{array}{l}\text { Fiscal Cost of } \\
\text { the Reform** }\end{array}$ & $\begin{array}{l}\text { Net Impact of } \\
\text { Change in } \\
\text { Financing*** }\end{array}$ & $\begin{array}{c}\text { Private } \\
\text { Voluntary } \\
\text { Saving**** }\end{array}$ \\
\hline 1974 & 22.9 & 0 & 0 & 0 & 6.3 \\
\hline 1975 & 11.8 & 0 & 0 & 0 & -5.8 \\
\hline 1976 & 18.3 & 0 & 0 & 0 & 1.6 \\
\hline 1977 & 14.4 & 0 & 0 & 0 & 0.1 \\
\hline 1978 & 16.4 & 0 & 0 & 0 & 3.4 \\
\hline 1979 & 16.2 & 0 & 0 & 0 & 4.9 \\
\hline 1980 & 17.6 & 0 & 0 & 0 & 4.3 \\
\hline 1981 & 12.1 & 1.3 & -1.5 & -0.2 & 7.5 \\
\hline 1982 & 6.2 & 2.6 & -4.8 & -2.2 & 4.6 \\
\hline 1983 & 8.4 & 3.1 & -4.8 & -1.7 & 4.7 \\
\hline 1984 & 6.9 & 3.8 & -4.8 & -1.0 & 4.2 \\
\hline 1985 & 9.7 & 4.5 & -4.6 & -0.1 & 4.8 \\
\hline 1986 & 12.9 & 3.9 & -4.7 & -0.8 & 7.4 \\
\hline 1987 & 18.8 & 4.7 & -4.8 & -0.2 & 10.9 \\
\hline 1988 & 24.2 & 4.2 & -4.7 & -0.5 & 10.2 \\
\hline 1989 & 25.5 & 6.4 & -4.5 & 1.9 & 12.1 \\
\hline 1990 & 25.8 & 9.0 & -5.3 & 3.7 & 9.8 \\
\hline 1991 & 25.4 & 8.3 & -5.3 & 3.0 & 10.3 \\
\hline 1992 & 25.9 & 7.3 & -5.1 & 2.2 & 11.7 \\
\hline 1993 & 24.7 & 8.3 & -5.4 & 2.9 & 10.3 \\
\hline 1994 & 26.2 & 8.0 & -5.6 & 2.4 & 12.1 \\
\hline
\end{tabular}

Source: Holzmann (1997), Hachette(1997)

* Contributions to private system

** Includes deficit of old system and value of recognition bonds redeemed

*** Sum of previous two columns, corresponds to Holzmann's measure

$* * * *$ Includes business and household saving 
Table 2 - Summary Statistics of Household Saving Rates

\begin{tabular}{|l|c|}
\hline \multicolumn{1}{|c|}{ Statistic } & Saving Rate \\
\hline mean & 0.087 \\
\hline median & 0.165 \\
\hline standard error & 0.373 \\
\hline interquartile range & 0.434 \\
\hline minimum & -1.49 \\
\hline maximum & 0.896 \\
\hline
\end{tabular}

Table 3- Saving Rates for Non-Tax Payers by Social Security Coverage Status

\begin{tabular}{|l|c|c|c|c|}
\hline & mean & median & $\begin{array}{c}\text { standard } \\
\text { error }\end{array}$ & $\begin{array}{c}\text { interquartile } \\
\text { range }\end{array}$ \\
\hline PAYGO System (heads 45 to 65) \\
\hline covered & 0.075 & 0.150 & 0.326 & 0.393 \\
\hline non-covered & 0.064 & 0.161 & 0.357 & 0.418 \\
\hline Private System (heads <40) & -0.027 & 0.056 & 0.391 & 0.451 \\
\hline covered & -0.097 & 0.012 & 0.441 & 0.564 \\
\hline non-covered & & & \\
\hline
\end{tabular}


Table 4 - Saving Rates for Tax Payers by Social Security Coverage Status

\begin{tabular}{|l|c|c|c|c|}
\hline & mean & median & $\begin{array}{c}\text { standard } \\
\text { error }\end{array}$ & $\begin{array}{c}\text { interquartile } \\
\text { range }\end{array}$ \\
\hline \multicolumn{5}{|l|}{ PAYGO System (heads 45 -65) } \\
\hline covered & 0.232 & 0.283 & 0.301 & 0.329 \\
\hline non-covered & 0.322 & 0.365 & 0.314 & 0.323 \\
\hline Private System (heads $<40$ ) \\
\hline covered & 0.200 & 0.252 & 0.297 & 0.352 \\
\hline non-covered & 0.161 & 0.192 & 0.342 & 0.466 \\
\hline
\end{tabular}

Table 5 - Characteristics of Non-Tax Payers by Social Security Coverage Status

\begin{tabular}{|l|c|c|c|c|}
\hline \multirow{2}{*}{} & \multicolumn{2}{|c|}{ PAYGO System (head 45-65) } & \multicolumn{2}{c|}{ Private System (head <40) } \\
\cline { 2 - 5 } & covered & non-covered & covered & non-covered \\
\hline married & 0.796 & 0.771 & 0.872 & 0.883 \\
& $(0.403)$ & $(0.421)$ & $(0.334)$ & $(0.322)$ \\
\hline male & 0.803 & 0.820 & 0.895 & 0.879 \\
& $(0.398)$ & $(0.385)$ & $(0.307)$ & $(0.327)$ \\
\hline adults & 3.19 & 3.19 & 2.11 & 2.14 \\
& $(1.45)$ & $(1.53)$ & $(0.625)$ & $(0.727)$ \\
\hline children & 1.26 & 1.06 & 1.86 & 2.25 \\
& $(1.31)$ & $(1.28)$ & $(1.20)$ & $(1.41)$ \\
\hline college & 0.061 & 0.061 & 0.085 & 0.045 \\
& $(0.240)$ & $(0.239)$ & $(0.279)$ & $(0.207)$ \\
\hline age & 52.04 & 53.63 & 30.84 & 32.70 \\
& $(5.27)$ & $(5.84)$ & $(4.85)$ & $(4.74)$ \\
\hline income & $1,016,038$ & $1,077,477$ & 659,319 & 538,830 \\
& $(677,833)$ & $(766,185)$ & $(432,453)$ & $(364,244)$ \\
\hline
\end{tabular}


Table 6 - Characteristics of Tax Payers by Social Security Coverage Status

\begin{tabular}{|l|c|c|c|c|}
\hline \multirow{2}{*}{} & \multicolumn{2}{|c|}{ PAYGO System (head 45-65) } & \multicolumn{2}{c|}{ Private System (head <40) } \\
\cline { 2 - 5 } & covered & non-covered & covered & non-covered \\
\hline married & 0.778 & 0.922 & 0.889 & 0.856 \\
& $(0.417)$ & $(0.268)$ & $(0.315)$ & $(0.352)$ \\
\hline male & 0.811 & 0.947 & 0.927 & 0.919 \\
& $(0.392)$ & $(0.225)$ & $(0.261)$ & $(0.274)$ \\
\hline adults & 3.09 & 3.19 & 2.09 & 2.05 \\
& $(1.20)$ & $(1.25)$ & $(0.567)$ & $(0.536)$ \\
\hline children & 0.959 & 0.825 & 1.69 & 1.98 \\
& $(1.17)$ & $(1.19)$ & $(1.11)$ & $(1.29)$ \\
\hline college & 0.522 & 0.427 & 0.678 & 0.469 \\
& $(0.500)$ & $(0.496)$ & $(0.468)$ & $(0.501)$ \\
\hline age & 52.08 & 54.52 & 32.66 & 33.40 \\
& $(5.27)$ & $(6.15)$ & $(3.92)$ & $(1.05)$ \\
\hline income & $4,537,849$ & $6,304,679$ & $3,360,573$ & $3,602,995$ \\
& $(2,882,140)$ & $(4,282,981)$ & $(2,050,365)$ & $(2,965,028)$ \\
\hline
\end{tabular}


Figure 3 - Earnings Profiles by Coverage Status

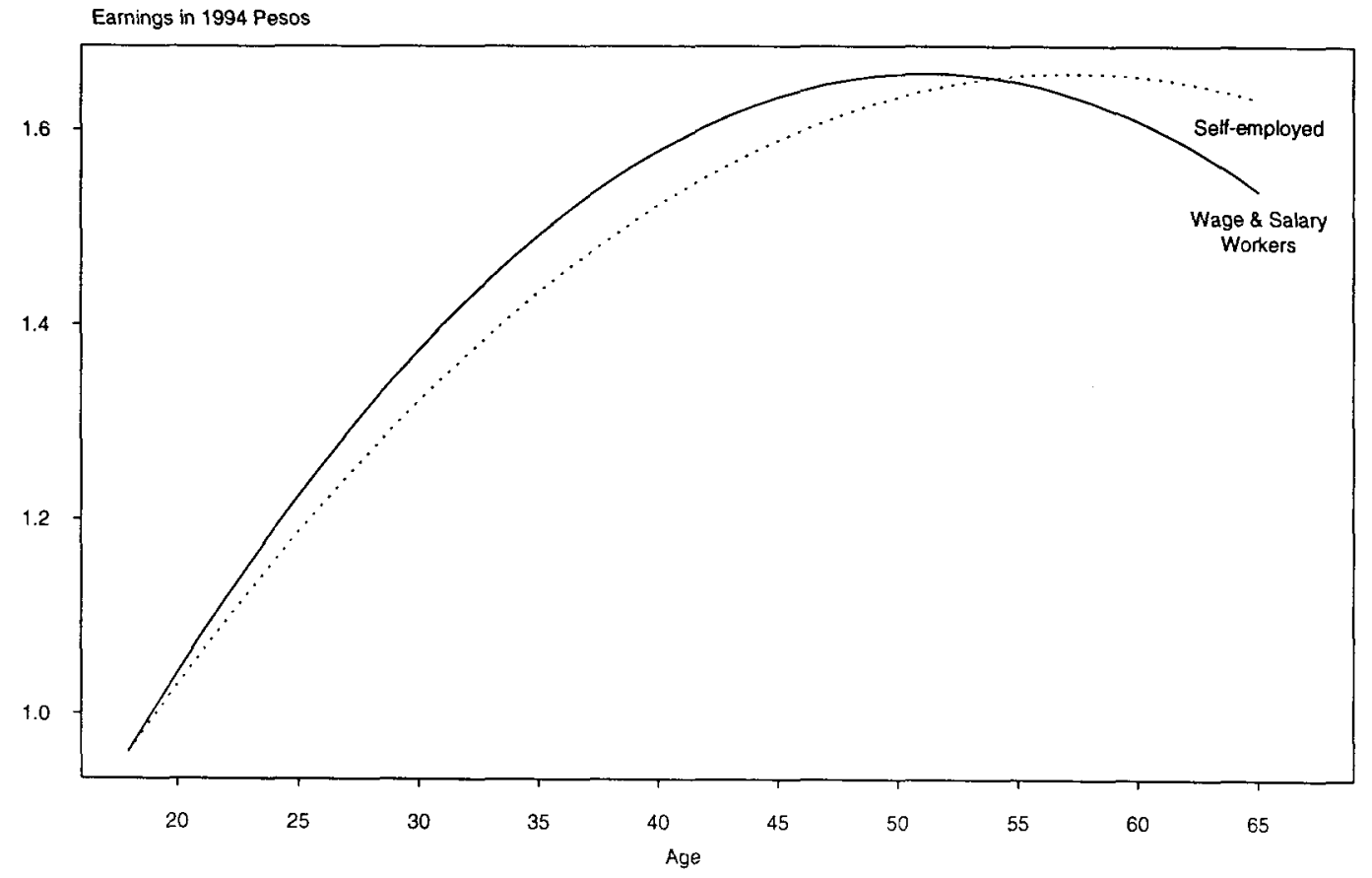


Table 7 - Correlations Among Variables for Non-Tax Payers

\begin{tabular}{|c|c|c|c|c|c|c|c|c|c|c|c|}
\hline & 1 & 2 & 3 & 4 & 5 & 6 & 7 & 8 & 9 & 10 & 11 \\
\hline 1. saving rate & 1 & & & & & & & & & & \\
\hline 2. married & -0.09 & 1 & & & & & & & & & \\
\hline 3. male & -0.07 & 0.71 & 1 & & & & & & & & \\
\hline 4. adults & 0.09 & 0.21 & 0.21 & 1 & & & & & & & \\
\hline 5. children & -0.14 & 0.23 & 0.15 & -0.02 & 1 & & & & & & \\
\hline 6. college & 0.02 & -0.13 & -0.09 & -0.07 & -0.08 & 1 & & & & & \\
\hline 7. age & 0.17 & -0.11 & -0.12 & 0.41 & -0.23 & -0.01 & 1 & & & & \\
\hline 8. new & -0.15 & 0.12 & 0.11 & -0.44 & 0.29 & 0.03 & -0.89 & 1 & & & \\
\hline 9. $\operatorname{cov}$ & 0.01 & 0.04 & 0.02 & -0.11 & 0.04 & 0.04 & -0.27 & 0.23 & 1 & & \\
\hline 10. new*cov & -0.08 & 0.09 & 0.10 & -0.35 & 0.17 & 0.05 & -0.73 & 0.78 & 0.60 & 1 & \\
\hline 11. income & 0.34 & -0.08 & -0.09 & 0.31 & -0.20 & 0.28 & 0.35 & -0.34 & -0.06 & -0.22 & 1 \\
\hline
\end{tabular}

Table 8 - Correlations Among Variables for Tax Payers

\begin{tabular}{|c|c|c|c|c|c|c|c|c|c|c|c|}
\hline & 1 & 2 & 3 & 4 & 5 & 6 & 7 & 8 & 9 & 10 & 11 \\
\hline 1. saving rate & 1 & & & & & & & & & & \\
\hline 2. married & -0.02 & 1 & & & & & & & & & \\
\hline 3. male & 0.00 & 0.67 & 1 & & & & & & & & \\
\hline 4. adults & 0.05 & 0.21 & 0.17 & 1 & & & & & & & \\
\hline 5. children & -0.15 & 0.22 & 0.13 & -0.19 & 1 & & & & & & \\
\hline 6. college & 0.02 & 0.00 & 0.06 & -0.19 & 0.02 & 1 & & & & & \\
\hline 7. age & 0.17 & -0.02 & -0.07 & 0.47 & -0.32 & -0.13 & 1 & & & & \\
\hline 8. new & -0.15 & 0.06 & 0.09 & -0.49 & 0.35 & 0.14 & -0.90 & 1 & & & \\
\hline 9. $\operatorname{cov}$ & 0.01 & -0.07 & -0.09 & -0.09 & 0.02 & 0.16 & -0.20 & 0.15 & 1 & & \\
\hline 10. new* ${ }^{*} \operatorname{cov}$ & -0.08 & 0.06 & 0.07 & -0.35 & 0.20 & 0.20 & -0.67 & 0.73 & 0.58 & 1 & \\
\hline 11. income & 0.38 & 0.10 & 0.09 & 0.16 & -0.03 & 0.23 & 0.31 & -0.30 & -0.19 & -0.23 & 1 \\
\hline
\end{tabular}


Table 9 - Estimation of Saving Function for Non-Tax Payers

\begin{tabular}{|c|c|c|c|c|c|c|c|c|}
\hline \multirow[b]{3}{*}{ constant } & \multicolumn{4}{|c|}{ Robust Regression } & \multicolumn{4}{|c|}{ Median Regression } \\
\hline & \multicolumn{2}{|c|}{$\begin{array}{c}\text { Saving w/ } \\
\text { Durable Streams }\end{array}$} & \multicolumn{2}{|c|}{$\begin{array}{c}\text { Saving w/o } \\
\text { Durable Streams }\end{array}$} & \multicolumn{2}{|c|}{$\begin{array}{c}\text { Saving w/ Durable } \\
\text { Streams }\end{array}$} & \multicolumn{2}{|c|}{$\begin{array}{c}\text { Saving w/o } \\
\text { Durable Streams }\end{array}$} \\
\hline & $\begin{array}{l}-0.152 \\
(1.71)\end{array}$ & $\begin{array}{r}-0.142 \\
(1.67)\end{array}$ & $\begin{array}{r}-0.185 \\
(1.67)\end{array}$ & $\begin{array}{l}-0.169 \\
(1.61)\end{array}$ & $\begin{array}{l}-0.155 \\
(1.37)\end{array}$ & $\begin{array}{r}-0.173 \\
(1.59)\end{array}$ & $\begin{array}{r}-0.173 \\
(1.28)\end{array}$ & $\begin{array}{r}-0.216 \\
(1.71)\end{array}$ \\
\hline married & $\begin{array}{r}-0.039 \\
(1.25)\end{array}$ & $\begin{array}{r}-0.046 \\
(1.54)\end{array}$ & $\begin{array}{r}-0.046 \\
(1.19)\end{array}$ & $\begin{array}{r}-0.055 \\
(1.51)\end{array}$ & $\begin{array}{r}-0.045 \\
(1.15)\end{array}$ & $\begin{array}{r}-0.058 \\
(1.53)\end{array}$ & $\begin{array}{r}-0.049 \\
(1.02)\end{array}$ & $\begin{array}{r}-0.059 \\
(1.32)\end{array}$ \\
\hline male & $\begin{array}{r}-0.028 \\
(0.86)\end{array}$ & $\begin{array}{l}-0.008 \\
(0.26)\end{array}$ & $\begin{array}{r}-0.044 \\
(1.09)\end{array}$ & $\begin{array}{l}-0.016 \\
(0.43)\end{array}$ & $\begin{array}{r}-0.029 \\
(0.71)\end{array}$ & $\begin{array}{l}0.014 \\
(0.36)\end{array}$ & $\begin{array}{l}-0.069 \\
(1.39)\end{array}$ & $\begin{array}{l}0.009 \\
(0.19)\end{array}$ \\
\hline adults & $\begin{array}{l}0.019 \\
(2.47)\end{array}$ & $\begin{array}{r}-0.004 \\
(0.59)\end{array}$ & $\begin{array}{l}0.019 \\
(2.03)\end{array}$ & $\begin{array}{l}-0.013 \\
(1.41)\end{array}$ & $\begin{array}{l}0.019 \\
(1.99)\end{array}$ & $\begin{array}{r}-0.009 \\
(0.89)\end{array}$ & $\begin{array}{l}0.021 \\
(1.84)\end{array}$ & $\begin{array}{r}-0.017 \\
(1.49)\end{array}$ \\
\hline children & $\begin{array}{l}-0.024 \\
(3.77)\end{array}$ & $\begin{array}{r}-0.017 \\
(2.78)\end{array}$ & $\begin{array}{l}-0.031 \\
(3.83)\end{array}$ & $\begin{array}{l}-0.021 \\
(2.71)\end{array}$ & $\begin{array}{l}-0.019 \\
(2.29)\end{array}$ & $\begin{array}{l}-0.13 \\
(1.67)\end{array}$ & $\begin{array}{l}-0.023 \\
(2.38)\end{array}$ & $\begin{array}{r}-0.018 \\
(1.99)\end{array}$ \\
\hline college & $\begin{array}{l}0.022 \\
(1.25)\end{array}$ & $\begin{array}{r}-0.067 \\
(3.73)\end{array}$ & $\begin{array}{l}0.035 \\
(1.58)\end{array}$ & $\begin{array}{l}-0.083 \\
(3.73)\end{array}$ & $\begin{array}{l}0.049 \\
(2.17)\end{array}$ & $\begin{array}{r}-0.049 \\
(2.16)\end{array}$ & $\begin{array}{l}0.051 \\
(1.86)\end{array}$ & $\begin{array}{r}-0.069 \\
(2.59)\end{array}$ \\
\hline age & $\begin{array}{l}0.005 \\
(3.38)\end{array}$ & $\begin{array}{l}0.002 \\
(1.67)\end{array}$ & $\begin{array}{l}0.007 \\
(3.72)\end{array}$ & $\begin{array}{l}0.003 \\
(1.84)\end{array}$ & $\begin{array}{l}0.006 \\
(2.85)\end{array}$ & $\begin{array}{l}0.003 \\
(1.77)\end{array}$ & $\begin{array}{l}0.007 \\
(3.17)\end{array}$ & $\begin{array}{l}0.005 \\
(2.08)\end{array}$ \\
\hline income & & $\begin{array}{l}1.9 \mathrm{E}-07 \\
(12.83)\end{array}$ & & $\begin{array}{l}2.6 \mathrm{E}-08 \\
(14.19)\end{array}$ & & $\begin{array}{l}1.9 \mathrm{E}-07 \\
(10.28)\end{array}$ & & $\begin{array}{r}2.6 \mathrm{E}-07 \\
(11.81)\end{array}$ \\
\hline new & $\begin{array}{l}0.023 \\
(0.05)\end{array}$ & $\begin{array}{l}0.038 \\
(0.89)\end{array}$ & $\begin{array}{c}0.018 \\
(0.33)\end{array}$ & $\begin{array}{l}0.038 \\
(0.72)\end{array}$ & $\begin{array}{c}0.002 \\
(0.30)\end{array}$ & $\begin{array}{c}0.029 \\
(0.52)\end{array}$ & $\begin{array}{c}-0.008 \\
(0.11)\end{array}$ & $\begin{array}{c}0.029 \\
(0.46)\end{array}$ \\
\hline covered & $\begin{array}{c}0.006 \\
(0.03)\end{array}$ & $\begin{array}{c}0.019 \\
(0.85)\end{array}$ & $\begin{array}{c}-0.006 \\
(0.19)\end{array}$ & $\begin{array}{l}0.013 \\
(0.45)\end{array}$ & $\begin{array}{c}0.013 \\
(0.44)\end{array}$ & $\begin{array}{c}0.018 \\
(0.61)\end{array}$ & $\begin{array}{c}0.006 \\
(0.16)\end{array}$ & $\begin{array}{c}0.009 \\
(0.26)\end{array}$ \\
\hline new*covered & $\begin{array}{c}0.051 \\
(1.44)\end{array}$ & $\begin{array}{c}0.024 \\
(0.71)\end{array}$ & $\begin{array}{c}0.069 \\
(1.58)\end{array}$ & $\begin{array}{c}0.032 \\
(0.078)\end{array}$ & $\begin{array}{c}0.058 \\
(1.29)\end{array}$ & $\begin{array}{c}0.046 \\
(1.06)\end{array}$ & $\begin{array}{c}0.093 \\
(1.72)\end{array}$ & $\begin{array}{l}0.063 \\
(1.25)\end{array}$ \\
\hline
\end{tabular}

t-statistics are in parentheses, 1801 observations 
Table 10 - Estimation of Saving Function for Tax Payers

\begin{tabular}{|l|c|c|c|c|c|c|c|c|c|}
\hline & \multicolumn{3}{|c|}{ Robust Regression } & \multicolumn{3}{c|}{ Median Regression } \\
\hline & \multicolumn{2}{|c|}{$\begin{array}{c}\text { Saving w/ Durable } \\
\text { Streams }\end{array}$} & \multicolumn{2}{c|}{$\begin{array}{c}\text { Saving w/o } \\
\text { Durable Streams }\end{array}$} & \multicolumn{2}{c|}{$\begin{array}{c}\text { Saving w/ Durable } \\
\text { Streams }\end{array}$} & \multicolumn{2}{c|}{$\begin{array}{c}\text { Saving w/o } \\
\text { Durable Streams }\end{array}$} \\
\hline \multirow{2}{*}{ constant } & 0.351 & 0.375 & 0.361 & 0.387 & 0.352 & 0.376 & 0.333 & 0.498 \\
& $(3.24)$ & $(3.74)$ & $(2.88)$ & $(3.33)$ & $(2.46)$ & $(3.47)$ & $(2.56)$ & $(4.67)$ \\
\hline married & -0.034 & -0.055 & -0.036 & -0.061 & -0.025 & -0.042 & -0.043 & -0.042 \\
& $(0.99)$ & $(1.72)$ & $(0.91)$ & $(1.66)$ & $(0.55)$ & $(1.25)$ & $(1.02)$ & $(1.25)$ \\
\hline male & 0.024 & 0.013 & 0.027 & 0.018 & 0.036 & -0.013 & 0.026 & -0.017 \\
& $(0.61)$ & $(0.37)$ & $(0.61)$ & $(0.43)$ & $(0.48)$ & $(0.35)$ & $(0.55)$ & $(0.45)$ \\
\hline adults & -0.011 & -0.011 & -0.015 & -0.014 & -0.016 & -0.013 & -0.015 & -0.022 \\
& $(1.16)$ & $(1.21)$ & $(1.34)$ & $(1.35)$ & $(1.28)$ & $(1.32)$ & $(1.28)$ & $(2.36)$ \\
\hline children & -0.021 & -0.031 & -0.025 & -0.036 & -0.024 & -0.032 & -0.028 & -0.041 \\
& $(2.76)$ & $(4.47)$ & $(2.84)$ & $(4.48)$ & $(2.43)$ & $(4.24)$ & $(3.05)$ & $(5.47)$ \\
\hline college & -0.002 & -0.104 & 0.002 & -0.114 & 0.008 & -0.084 & 0.026 & -0.105 \\
& $(0.08)$ & $(3.84)$ & $(0.07)$ & $(3.61)$ & $(0.02)$ & $(2.86)$ & $(0.75)$ & $(3.63)$ \\
\hline age & 0.002 & -0.001 & 0.003 & 0.001 & 0.001 & -0.001 & 0.004 & 0.001 \\
& $(0.86)$ & $(0.51)$ & $(1.51)$ & $(0.19)$ & $(0.51)$ & $(0.54)$ & $(1.83)$ & $(0.68)$ \\
\hline income & & $3.5 \mathrm{E}-08$ & & $3.9 \mathrm{E}-08$ & & $3.7 \mathrm{E}-08$ & & $4.2 \mathrm{E}-08$ \\
& & $(12.38)$ & & $(12.06)$ & & $(12.06)$ & & $(14.24)$ \\
\hline new & -0.128 & -0.072 & -0.155 & -0.091 & -0.121 & -0.091 & -0.165 & -0.138 \\
& $(2.63)$ & $(1.59)$ & $(2.75)$ & $(1.72)$ & $(1.89)$ & $(1.72)$ & $(2.82)$ & $(2.86)$ \\
\hline covered & -0.093 & -0.029 & -0.111 & -0.036 & -0.077 & -0.036 & -0.121 & -0.033 \\
& $(3.57)$ & $(1.19)$ & $(3.69)$ & $(1.25)$ & $(2.22)$ & $(1.25)$ & $(3.85)$ & $(1.24)$ \\
\hline new*covered & 0.123 & 0.078 & 0.146 & 0.094 & 0.105 & 0.094 & 0.180 & 0.129 \\
& $(3.34)$ & $(2.28)$ & $(3.44)$ & $(2.38)$ & $(2.16)$ & $(2.38)$ & $(4.08)$ & $(3.53)$ \\
\hline
\end{tabular}

t-statistics are in parentheses, 1031 observations 
Table 11 - Average Real Rate of Return on Social Security Pension Funds

\begin{tabular}{|l|c|}
\hline \multicolumn{1}{|c|}{ Year } & $\begin{array}{c}\text { Real Rate of } \\
\text { Return }\end{array}$ \\
\hline 1981 & 21.3 \\
\hline 1982 & 28.8 \\
\hline 1983 & 21.3 \\
\hline 1984 & 3.5 \\
\hline 1985 & 13.4 \\
\hline 1986 & 12.3 \\
\hline 1987 & 5.4 \\
\hline 1988 & 6.4 \\
\hline 1989 & 6.9 \\
\hline 1990 & 11.5 \\
\hline 1991 & 29.7 \\
\hline 1992 & 3.1 \\
\hline 1993 & 16.2 \\
\hline 1994 & 18.2 \\
\hline 1995 & -2.5 \\
\hline
\end{tabular}

